\title{
Microwave-assisted synthesis of $\mathrm{ZnO}$ micro-javelins $\dagger$
}

\author{
Sibu C. Padmanabhan, $\uparrow^{\star}{ }^{* a}$ Deirdre Ledwith, ${ }^{a}$ Suresh C. Pillai, ${ }^{b}$ Declan E. McCormack ${ }^{c}$ and John M. Kelly ${ }^{* a}$
}

\author{
Received 25th June 2009, Accepted 2nd October 2009 \\ First published as an Advance Article on the web 5th November 2009 \\ DOI: $10.1039 / b 912537 \mathbf{j}$
}

\begin{abstract}
The microwave (MW)-assisted formation of $\mathrm{ZnO}$ micro-javelins from zinc nitrate and urea in aqueous solution is described. The particles (named as 'micro-javelins' because of their high aspect ratio and needle-like tips) grow hexagonally with well-defined facets in the $\langle 01 \overline{1} 0\rangle$ direction and pointed tips in (0001) direction. Powder X-ray diffraction patterns show the appearance of a strikingly dominant (1000) orientation. Scanning electron microscopy (SEM) and transmission electron microscopy (TEM) investigations reveal the morphological evolution of these hexagonal $\mathrm{ZnO}$ particles with time. The effect of precursor concentrations, counterion type and MW irradiation power and their consequent influence on $\mathrm{pH}$ and $\mathrm{Zn}^{2+}$ ion concentration are investigated. A mechanism for the formation of the micro-javelins is postulated. The microwave induced supersaturation of $\mathrm{Zn}(\mathrm{OH})^{+}$ species under the weakly basic $\mathrm{pH}$ condition and the initial growth through the $(000 \overline{1})$ direction (oxygen-rich face) are proposed to be the key factors that dictate the formation of these $\mathrm{ZnO}$ micro-javelins. The present one-step microwave process is a straightforward and a reproducible method for the bulk synthesis of defect-free $\mathrm{ZnO}$ micro-javelins, which would find potential applications in microelectronic devices (e.g. lasers, cantilevers in surface probing equipment, etc.).
\end{abstract}

\section{Introduction}

$\mathrm{ZnO}$, a wide band gap semiconductor $(3.37 \mathrm{eV})$, has a range of potential applications as photocatalysts, ${ }^{1}$ gas sensors, ${ }^{2}$ lasers,${ }^{3}$ displays, ${ }^{4}$ high-density optical storage devices ${ }^{5}$ and varistors. ${ }^{6}$ Recent research has focused on manipulating its shape into one-dimensional (1-D) rods, ${ }^{7}$ tubes,${ }^{8}$ belts, ${ }^{9}$ wires and rings ${ }^{10}$ that offer improved performance in terms of its optical, mechanical and electronic properties.

Solid-vapour phase sublimation is one of the established techniques in the preparation of 1-D $\mathrm{ZnO}$ nanoparticles. ${ }^{11} \mathrm{By}$ this method the growth of the reactants into the required 1-D structures is particularly sensitive to reaction conditions including the selection of carrier gas, its flow rate and the orientation of substrate, which are some of its limitations. Solution-growth, in this regard, may address some of the issues of the solid-vapour technique. ${ }^{12-15}$ The hydrothermal method is one of the widely used solution-growth techniques to synthesise size- and shape-controlled crystalline $\mathrm{ZnO}$ particles. ${ }^{16,17}$ The use of various precursor combinations including different zinc

${ }^{a}$ School of Chemistry, Trinity College, University of Dublin, Dublin, 2, Ireland.E-mail: jmkelly@tcd.ie; Fax: +353 1 6712826; Tel: +353 1 8961947

${ }^{b}$ Centre for Research in Engineering Surface Technology (CREST), FOCAS Institute, Dublin Institute of Technology, Camden Row, Dublin, 8, Ireland.E-mail: suresh.pillai@dit.ie; Fax: +3531 4027941; Tel: +353 14027946

'School of Chemical and Pharmaceutical Sciences, Dublin Institute of Technology, Kevin Street, Dublin, 8, Ireland. E-mail: declan. mccormack@dit.ie; Fax: +35314024989; Tel: +35314024778

$\dagger$ Electronic supplementary information (ESI) available: Extra structural, morphological and thermodynamic data. See DOI: $10.1039 / \mathrm{b} 912537 \mathrm{j}$

\$ Current address: Tyndall National Institute, University College of Cork, Lee Maltings, Prospect Row, Cork, Ireland. Tel.: +353 21 4904406; fax: +353 21 4904467. E-mail: sibu.padmanabhan@tyndall.ie. salts, ${ }^{18}$ hydrolysing agents (amines, ${ }^{19}$ acids $^{20}$ and bases ${ }^{21}$ ) as well as various polymeric agents ${ }^{22}$ and surfactants ${ }^{23}$ can be helpful in defining the growth directions by capping/modifying the basic building units. ${ }^{24-26}$

The controlled solution-growth of $\mathrm{ZnO}$ particles with welldefined morphologies, however, is still a challenge and the mechanism underlying such processes is unclear. The oriented/ controlled growth of capped $\mathrm{Zn}^{2+}$ species, microemulsions, ${ }^{27}$ and micellar ${ }^{28}$ building units into various size- and shape-controlled $\mathrm{ZnO}$ particles is interesting but complicated. In 1990 Tsuchida and Kitajima reported a more straightforward synthetic procedure for the bulk chemical synthesis of well-defined $\mathrm{ZnO}$ hexagonal prisms. The procedure involved the hydrolysis of a zinc nitrate solution at $95{ }^{\circ} \mathrm{C}$ in the presence of urea. ${ }^{29} \mathrm{Such}$ a procedure was straightforward in that it did not involve any further additives. However, the procedure did not yield particles of a single morphology but a mixture of needles, rods and spindles and the procedure yielded only small quantities of products.

As part of a programme to develop routes to synthesise $\mathrm{ZnO}$ nano- and micro-materials with optimal electronic and optical properties, we have previously observed that a one-step microwave (MW)-assisted reaction between zinc nitrate and urea in aqueous media yields $\mathrm{ZnO}$ micro-javelins ${ }^{30}$ Microwave synthesis is chosen because of its higher reaction rates, rapid volumetric heating, higher yields of products and energy saving prospects. ${ }^{31,32}$ This paper reports a systematic study of the various parameters that influence the javelin formation and proposes a mechanistic pathway by which micro-javelins are formed. The effects of MW energy and irradiation time, influence of precursors (counterions), precursor concentrations, $\mathrm{pH}$ and $\mathrm{Zn}^{2+}$ ion concentration on the micro-javelin formation are discussed in detail. This, to the best of our knowledge, is a first systematic study report describing the MW growth of such particles. The process is rapid and reproducible compared to the 
conventional heating and hydrothermal routes and also yields large quantities (up to $90 \%$ ) of $\mathrm{ZnO}$ micro-javelins. The difference of our method from the reported ones is its ability to produce monodispersed $\mathrm{ZnO}$ micro-javelins with a high yield.

\section{Materials and methods}

\section{Materials}

$\mathrm{Zn}\left(\mathrm{NO}_{3}\right)_{2} \cdot 6 \mathrm{H}_{2} \mathrm{O}, \quad \mathrm{Zn}\left(\mathrm{OOCCH}_{3}\right)_{2} \cdot 2 \mathrm{H}_{2} \mathrm{O}$ and $\mathrm{ZnSO}_{4}$ were purchased from Aldrich and $\mathrm{CO}\left(\mathrm{NH}_{2}\right)_{2}$ and $\mathrm{ZnCl}_{2}$ from $\mathrm{BDH}$. The chemicals were used without further purification. Millipore water was used for all experiments.

\section{Methods}

In a typical experiment, aqueous solutions of $40 \mathrm{~mL}$ each of $10 \mathrm{mM}$ zinc nitrate and $100 \mathrm{mM}$ urea were mixed in a Teflon bomb (Savillex Digestion vessel equipped with pressure releasable valve; volume $120 \mathrm{~mL}$, height $16 \mathrm{~cm}$ and outer diameter $50 \mathrm{~mm}$ ), stirred for $10 \mathrm{~min}$ and then irradiated at $150 \mathrm{~W}$ for 24 min using a domestic microwave oven (850 W Samsung FE22). The sample was then allowed to cool to room temperature ( $20 \mathrm{~h}$ of cooling). The precipitate was then separated by filtration $(0.45 \mu \mathrm{m}$ membrane filter $)$ and dried at $80^{\circ} \mathrm{C}$ in an air oven $(20 \mathrm{~h})$ before further analyses. Samples were also collected after sudden release of pressure (without the cooling stage) under otherwise similar experimental conditions and compared. Experiments involving different zinc salts such as zinc acetate, zinc chloride and zinc sulfate have also been carried out and results compared. It should be noted that the experiments carried out in this report were in a different microwave oven compared to our earlier report, where a domestic microwave oven of $750 \mathrm{~W}$ power was used, ${ }^{30}$ and hence needed slightly different MW irradiation times to achieve similar particles.

\section{Characterisation}

The $\mathrm{pH}$ of the reactant mixture as well as the product solution was measured using a Metrohm $632 \mathrm{pH}$-meter (Switzerland). Soluble zinc species concentrations of the microwave treated solutions were determined by complexometric titration (classic Zn-EDTA titration). Room temperature powder XRD patterns of the samples were recorded using a Siemens D 500 X-ray diffractometer in the diffraction angle range $2 \theta \quad 10-70^{\circ}$ using $\mathrm{CuK} \alpha$ radiation. FTIR spectra of the samples in $\mathrm{KBr}$ pellets were recorded with a Perkin Elmer Spectrum One GX Spectrometer. Photoluminescence of the samples suspended in an ethylene glycol : water $(2: 1)$ mixture was recorded using a Varian Cary Eclipse Fluorescence spectrophotometer. The excitation source was a high intensity xenon lamp and the excitation wavelength was selected as $325 \mathrm{~nm}$. The morphology of the samples was imaged by field emission scanning electron microscopy (Hitachi S-4300 FESEM) and transmission electron microscopy (JEOL JEM 2100 electron microscope).

\section{Results}

Well-crystallised wurtzite $\mathrm{ZnO}$ micro-javelins have been prepared by a microwave induced reaction of zinc nitrate and
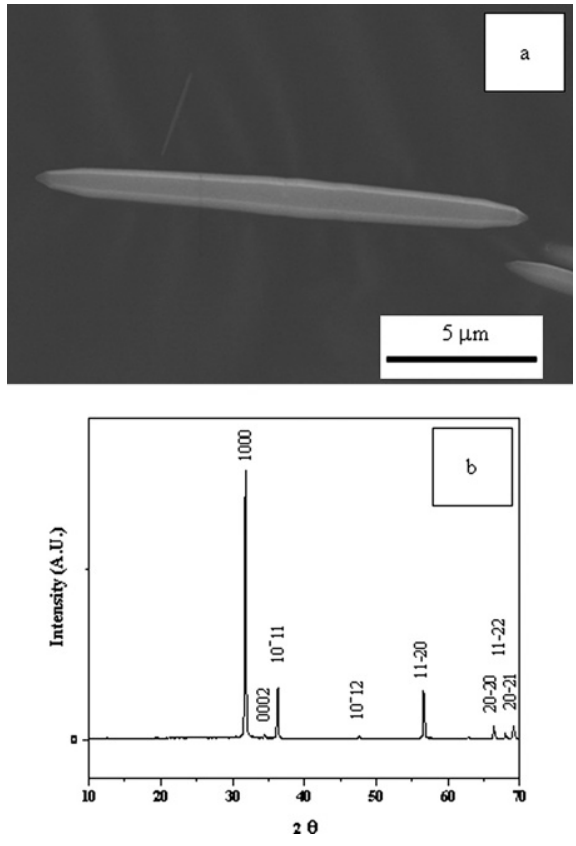

Fig. 1 (a) FESEM image and (b) XRD of $\mathrm{ZnO}$ micro-javelin(s) prepared by 24 min of MW irradiation between $80 \mathrm{~mL}$ aqueous solution of $5 \mathrm{mM}$ zinc nitrate and $50 \mathrm{mM}$ urea $(1: 10)$.

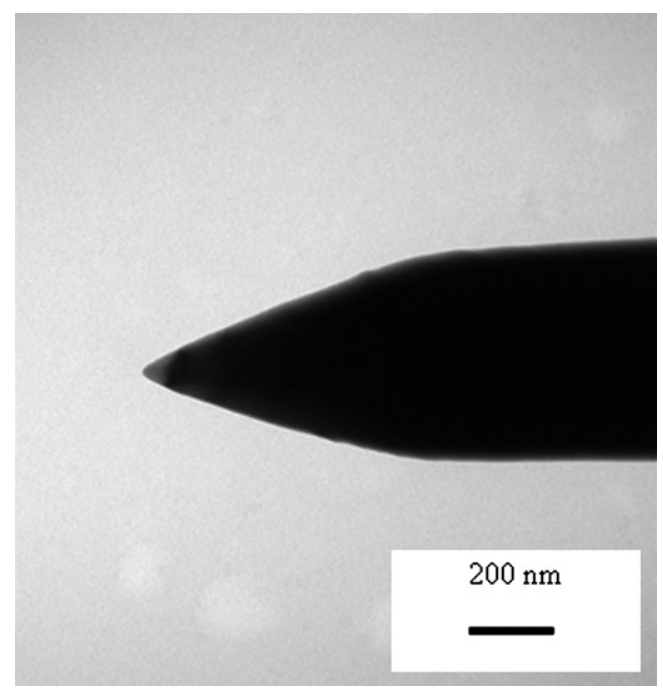

Fig. 2 TEM image of the pointed tip of a micro-javelin.

urea aqueous solution. A typical scanning electron microscope (SEM) image and X-ray diffraction (XRD) pattern of $\mathrm{ZnO}$ micro-javelins obtained by a 24 min of MW process between $80 \mathrm{~mL}$ aqueous solution of $5 \mathrm{mM}$ zinc nitrate and $50 \mathrm{mM}$ urea are presented in Fig. 1. The formation of well-defined microjavelin-like $\mathrm{ZnO}$ particles can be observed from the SEM. The XRD pattern corresponds to hexagonal, primitive, $P 6_{3} m c$ wurtzite $\mathrm{ZnO}$ unit cell structure (ICDD card no. 36-1451). Further, the powder sample shows an unusual XRD pattern, where the (1000) peak intensity is considerably dominant compared to all other diffraction peaks. This is uncommon for most wurtzite $\mathrm{ZnO}$ samples, where the (1011) peak is normally dominant. 
Furthermore, the extremely high intensity of the (1000) peak reflects the high crystallinity of micro-javelins. The micrographs show that the micro-javelins are grown with $\sim 14 \mu \mathrm{m}$ in length and $\sim 1.1 \mu \mathrm{m}$ in diameter and of a single morphology. Fig. 2 presents the TEM image of the pointed tip of one micro-javelin. A systematic investigation of this interesting growth phenomenon has been carried out and the results are presented here.

\section{Effect of precursor concentration}

In order to identify the optimum reactant concentrations that yield perfectly grown $\mathrm{ZnO}$ micro-javelins, experiments were conducted with different concentrations of urea and zinc nitrate. A ratio of zinc nitrate to urea of $1: 10(5 \mathrm{mM}: 50 \mathrm{mM})$ is found to produce a high yield of well-defined $\mathrm{ZnO}$ micro-javelins. No precipitate was formed when the zinc nitrate to urea ratio was $1: 100(5 \mathrm{mM}: 500 \mathrm{mM})$. At a $1: 1$ zinc nitrate to urea ratio
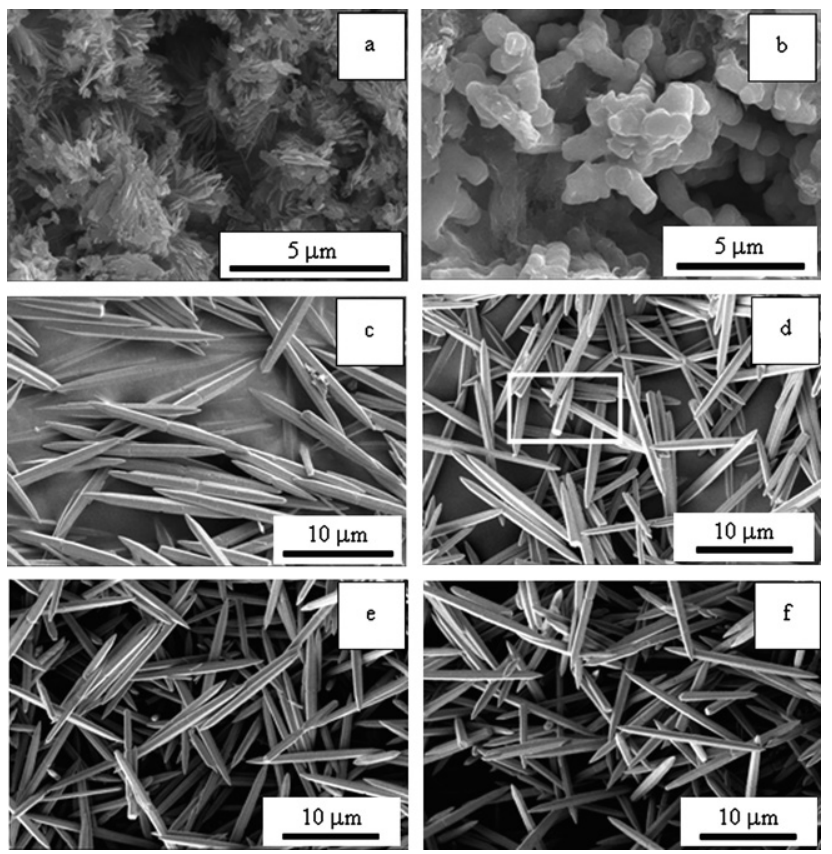

Fig. 3 SEM images of the samples obtained after irradiation for (a) $11 \mathrm{~min}$, (b) $13 \mathrm{~min}$, (c) $14 \mathrm{~min}$, (d) $17 \mathrm{~min}$, (e) $19 \mathrm{~min}$ and (f) $22 \mathrm{~min}$ at a power of $150 \mathrm{~W}$. A typical half-javelin is shown in the box in (d).
( $5 \mathrm{mM}: 5 \mathrm{mM}$ ), double-ended cone-like particles were observed where the particular structure appears to be formed by the lateral stacking of disc-like particles and the particles appear to grow down to form coupled cone-like structures (ESI $\dagger 1$ ). When the reaction was carried out with solutions containing $100 \mathrm{mM}$ zinc nitrate and $100 \mathrm{mM}$ urea $(1: 1)$, both $\mathrm{ZnO}$ micro-javelins and agglomerates were formed. This indicates that the zinc nitrate to urea ratio is crucial in the preferential growth of $\mathrm{ZnO}$ microjavelins with a single morphology and a zinc nitrate to urea ratio of $1: 10$ produces a maximum number of micro-javelins of uniform morphology. Therefore a $1: 10$ ratio of zinc nitrate to urea was selected for further experiments to investigate the growth mechanism.

\section{Effect of microwave energy and time of irradiation}

The effect of the period of irradiation was investigated by varying the time of reactions at a fixed power of $150 \mathrm{~W}$. XRD patterns of samples obtained at different MW irradiation time were recorded $(\mathrm{ESI} \uparrow 2) .12$ and $13 \mathrm{~min}$ irradiation produced mostly white precipitates with a mixture of $\mathrm{Zn}_{5}\left(\mathrm{CO}_{3}\right)_{2}(\mathrm{OH})_{6}$ (1) (ICDD card 19-1458) and $\mathrm{ZnO}$ structures. The $14 \mathrm{~min}$ irradiated sample on the other hand gave peaks corresponding to only wurtzite $\mathrm{ZnO}$ (ICDD card 36-1451). The (1000) peak showed a consistent yet remarkable rise in intensity compared to other peaks upon increasing the irradiation time further up to $24 \mathrm{~min}$.

The morphological evolution of the $\mathrm{ZnO}$ micro-javelins was followed using SEM, which led us to some interesting observations regarding the micro-javelin formation. Despite a few reports ${ }^{33,34}$ indicating the formation of such particles, no significant attempt has been made to understand the mechanism underlying the $\mathrm{ZnO}$ micro-javelin formation. Fig. 3 presents the SEM images of samples prepared by irradiating the solutions between $11 \mathrm{~min}$ and $22 \mathrm{~min}$ and the observations made are summarised in Table 1. The samples prepared at 11 and $12 \mathrm{~min}$ showed flaky plate-like structures without any particular orientation or stacking. The $13 \mathrm{~min}$ irradiated sample indicated a shaping up to spherical to rod-like kind of morphology. On the other hand that prepared with 14 min of irradiation (sample 5 in Table 1) showed the presence of $\mathrm{ZnO}$ micro-javelins, and a similar morphology was retained up to 24 min of irradiation.

FTIR spectra of the samples also demonstrate the structural evolution of the $\mathrm{ZnO}$ in terms of its shape and purity with the

Table 1 Growth of $\mathrm{ZnO}$ materials subjected to microwave irradiation between 10 and 24 min

\begin{tabular}{|c|c|c|c|c|c|c|c|}
\hline Sample & Irradiation time/min & $\mathrm{pH}$ & Dominant morphology & Length of particles/ $\mu \mathrm{m}$ & Width of particles/ $\mu \mathrm{m}$ & Aspect ratio & Yield $(\%)$ \\
\hline 2 & 11 & 6.81 & Precipitate & - & - & - & 5 \\
\hline 4 & 13 & 7.04 & Precipitate & - & - & - & 96 \\
\hline 5 & 14 & 7.38 & Javelins & $16.8 \pm 0.6$ & $1.2 \pm 0.1$ & 14.0 & 95 \\
\hline 6 & 15 & 8.62 & Javelins & $13.0 \pm 0.5$ & $0.9 \pm 0.1$ & 14.4 & 95 \\
\hline 7 & 16 & 8.72 & Javelins & $17.9 \pm 0.6$ & $1.4 \pm 0.1$ & 12.8 & 94 \\
\hline 10 & 19 & 9.13 & Javelins & $14.6 \pm 0.9$ & $1.1 \pm 0.1$ & 13.3 & 82 \\
\hline 11 & 20 & 9.31 & Javelins & $14.2 \pm 1.0$ & $1.1 \pm 0.1$ & 12.9 & 84 \\
\hline 12 & 22 & 9.56 & Javelins & $16.1 \pm 0.7$ & $1.1 \pm 0.1$ & 14.6 & 82 \\
\hline 13 & 24 & 9.75 & Javelins & $14.0 \pm 0.8$ & $1.1 \pm 0.1$ & 12.7 & 80 \\
\hline
\end{tabular}




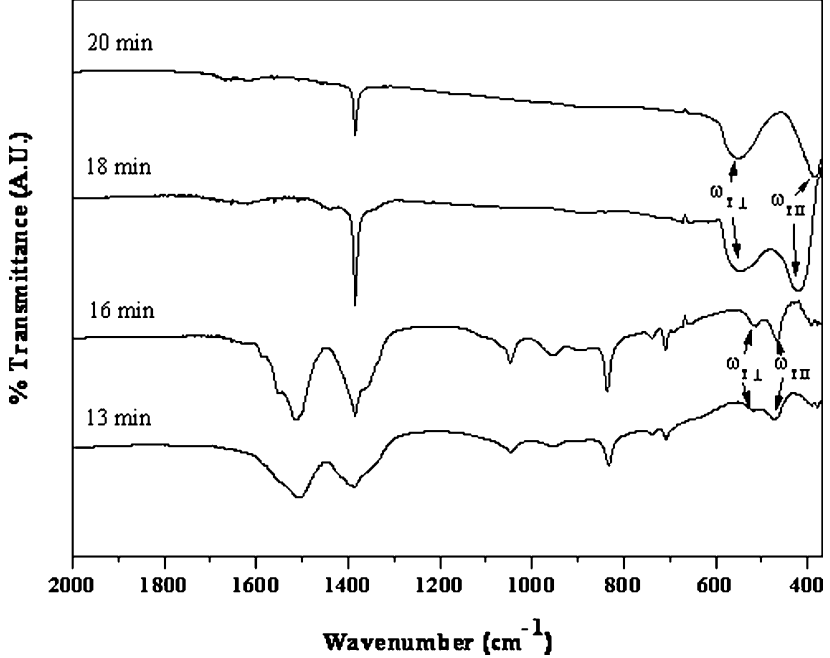

Fig. 4 FTIR spectra of $\mathrm{ZnO}$ particles obtained at different $\mathrm{MW}$ irradiation times.

time of MW irradiation (Fig. 4). FTIR spectra of samples irradiated for shorter times (those less than $16 \mathrm{~min}$ ) showed low intensity peaks possibly corresponding to the two transverse optical modes of $\mathrm{ZnO}$ wurtzite structure $\left(\omega_{\mathrm{T} \|}\right.$ at $473 \mathrm{~cm}^{-1}$ and $467 \mathrm{~cm}^{-1}$, and $\omega_{\mathrm{T} \perp}$ at $519 \mathrm{~cm}^{-1}$ and $514 \mathrm{~cm}^{-1}$ for the 13 and 16 min samples) ${ }^{35}$ while the longer time irradiated samples showed the presence of well developed spectral bands $\left(\omega_{\mathrm{T} \|}\right.$ at $418 \mathrm{~cm}^{-1}$ and $381 \mathrm{~cm}^{-1}$, and $\omega_{\mathrm{T} \perp}$ at $547 \mathrm{~cm}^{-1}$ and $551 \mathrm{~cm}^{-1}$ for the 18 and 20 min samples). ${ }^{35}$ These observations are consistent with the report by Verges et al., where the evolution of rod shaped particles from spheres was followed using FTIR. ${ }^{36}$ The presence of surface-bound species such as adsorbed or complexed species like $\mathrm{CO}_{3}{ }^{2-}, \mathrm{NO}_{3}{ }^{-}$and surface- $\mathrm{OH}$ species is identified from their corresponding spectral bands. Bands at $710 \mathrm{~cm}^{-1}$ and $739 \mathrm{~cm}^{-1}$ probably correspond to the $v_{4} \mathrm{CO}_{3}{ }^{2-}$ vibrations and the one at $836 \mathrm{~cm}^{-1}$ corresponds to the $v_{2} \mathrm{CO}_{3}{ }^{2-}$ vibration. ${ }^{37,38}$ All the samples showed a band at $1385 \mathrm{~cm}^{-1}$ indicating the presence of nitrate species complexed with the metal ion. ${ }^{39}$ The bands at 1360 , 1550 and $1587 \mathrm{~cm}^{-1}$ may be assigned to the symmetric and antisymmetric vibrations of carbonate. ${ }^{40,41}$ Further, a broad band centered at $3370 \mathrm{~cm}^{-1}\left(\nu_{\mathrm{O}-\mathrm{H}}\right)$ can be observed for the shorter time irradiated samples (13 and $16 \mathrm{~min}$ ) indicating the presence of surface adsorbed water molecules (ESI $\uparrow 3$ ). By contrast, the band corresponding to the $18 \mathrm{~min}$ irradiated sample showed only a weak band centered at $3480 \mathrm{~cm}^{-1}$. Thus these FTIR results confirm that extended ( $\geq 18 \mathrm{~min}$ ) microwave irradiation leads to the formation of $\mathrm{ZnO}$ particles with elongated morphology and with less adsorbed/complexed species.

\section{Influence of $\mathrm{pH}$ and $\mathrm{Zn}^{2+}$ ion concentration}

The $\mathrm{pH}$ during the microwave reaction has been monitored (Table 1 and Fig. 5). The solutions obtained on shorter times ( $\leq 10 \mathrm{~min}$ ) of $\mathrm{MW}$ irradiations, which did not cause $\mathrm{ZnO}$ precipitation, showed lower $\mathrm{pH}$ values $(\mathrm{pH}<6.8)$ compared to the other samples $(\mathrm{pH}>6.8)$. The solution irradiated for $11-13$ min, where precipitates had started to form, gave a $\mathrm{pH}$ 6.81-7.04. This indicates $\mathrm{pH} \approx 7$ as the 'critical solution $\mathrm{pH}$ ' for the

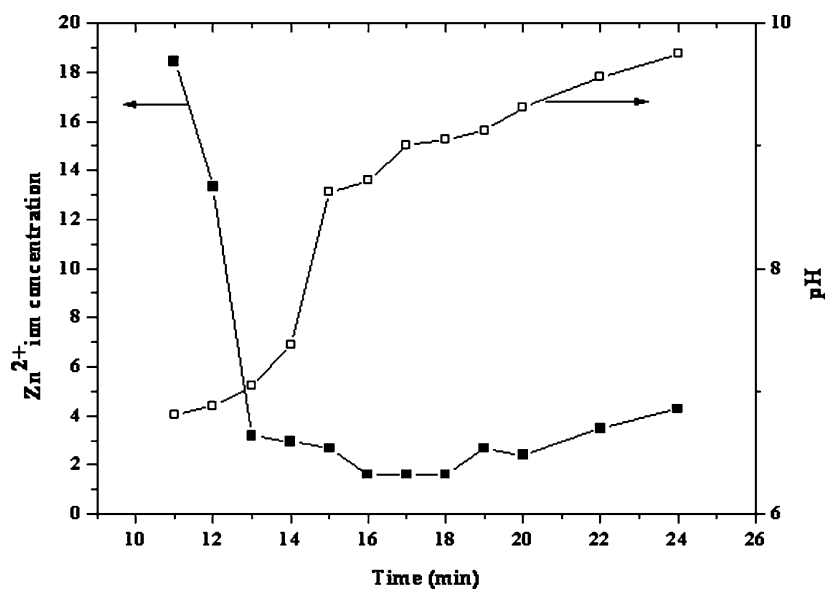

Fig. 5 Plots of $\mathrm{pH}$ and $\mathrm{Zn}^{2+}$ ion concentration vs. MW irradiation time at a power of $150 \mathrm{~W}$.

formation of $\mathrm{Zn}_{5}\left(\mathrm{CO}_{3}\right)_{2}(\mathrm{OH})_{6}$ (1) particles. ${ }^{42}$ Further, the solution $\mathrm{pH}$ showed a gradual increase with the extent of $\mathrm{MW}$ irradiation and the particles are completely transformed to wurtzite $\mathrm{ZnO}$ at a $\mathrm{pH}>7.04 .{ }^{42}$ The $\mathrm{pH}$ dependent $\mathrm{ZnO}$ precipitation has previously been reported and our results are consistent with those reports. ${ }^{43-45}$

A correlation between microwave irradiation time, $\mathrm{pH}$ and $\mathrm{Zn}^{2+}$ ion concentration was derived by determining the soluble $\mathrm{Zn}^{2+}$ ion concentration by means of the $\mathrm{Zn}$-EDTA titration of respective microwave irradiated solutions. Fig. 5 presents the profiles showing the evolution of $\mathrm{pH}$ and soluble zinc species as a consequence of increasing the $\mathrm{MW}$ irradiation time from $11 \mathrm{~min}$ to $24 \mathrm{~min}$. A higher soluble zinc species concentration can be observed at $\mathrm{pH}$ values less than 7 and as the $\mathrm{pH}$ goes up crossing the 'critical solution $\mathrm{pH}$ ' i.e. $\mathrm{pH} \approx 7$, a sudden decrease in the soluble zinc species concentration occurs. The lowest concentration of soluble zinc species is observed at $\mathrm{pH}$ values of $\sim 8.7$ to 9.05 , which can be assumed as the equilibrium concentration, and their concentration in the solution increases somewhat with a further increase in $\mathrm{pH}$. The occurrence of higher concentrations of soluble zinc species in solutions irradiated for longer times could be ascribed to their dissolution (possibly as $\left.\mathrm{Zn}(\mathrm{OH})_{4}{ }^{2-}\right)$ as a result of an increase in $\mathrm{pH}$ beyond that of the point of zero charge (PZC) of $\mathrm{ZnO}(\mathrm{ca} .9){ }^{18}$

It may be noted that the samples especially those prepared with $>17$ min of MW irradiation showed the presence of some halfjavelins. An etching from the middle portion of the javelins can also be observed in such samples. This could be attributed to the corresponding $\mathrm{pH}$ of the microwave treated solution (Table 1). When the particles are cooled in a solution with a $\mathrm{pH}$ near or above the PZC of $\mathrm{ZnO}$ particles, etching of $\mathrm{Zn}^{2+}$ may occur. Such a preferential etching is found to be happening from the axially middle portion of the $\mathrm{ZnO}$ micro-javelins (Fig. 6), which indicates it is a more susceptible region compared to other regions.

In order to confirm the influence of $\mathrm{pH}$ on the solubilisation of the zinc species/etching of the $\mathrm{ZnO}$ crystals, a number of further experiments have been carried out. Firstly the $\mathrm{pH}$ of the zinc nitrate-urea mixture was adjusted to 10 using $\mathrm{NH}_{4} \mathrm{OH}$ solution and then irradiated for $18 \mathrm{~min}$. In a second experiment, the reactant mixture was first irradiated for $14 \mathrm{~min}$, allowed to cool 

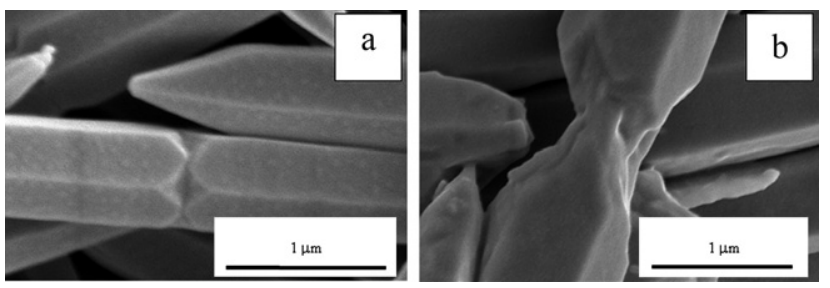

Fig. 6 SEM images showing the etching from the middle portion of the javelins (a) after $20 \mathrm{~min}$ reaction and (b) after $21 \mathrm{~min}$ at a power of $150 \mathrm{~W}$.
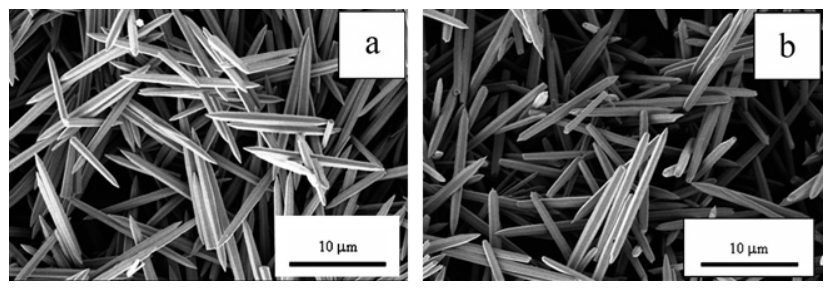

Fig. 7 (a) $\mathrm{ZnO}$ produced after immediate pressure release and (b) pressure released after cooling to room temperature. Samples prepared by reaction at $150 \mathrm{~W}$ for $20 \mathrm{~min}$.

down to room temperature, the $\mathrm{pH}$ adjusted to 10 with $\mathrm{NH}_{4} \mathrm{OH}$ and then the MW irradiation was carried out for a further $18 \mathrm{~min}$. Both the experiments produced micro-javelins with etched middle portion and a rough surface texture $(\mathrm{ESI} \uparrow 4)$. A corresponding increase in zinc species concentration was also observed in the solution substantiating the role of solution $\mathrm{pH}$.

\section{Effect of pressure release}

In order to understand the effect of pressure in the Teflon reaction vessel on the size and/or shape of the product, two types of experiments were initially conducted. In our preliminary studies $^{30}$ the pressure was released immediately after the MW irradiation whereas in the current study the vessel was allowed to cool to room temperature and only at that stage was the pressure reduced by opening the reactor vessel valve. Both procedures gave (1000) oriented crystalline $\mathrm{ZnO}$ micro-javelins as the product, but the second procedure produced slightly shorter $\mathrm{ZnO}$ particles $(\sim 14.2 \mu \mathrm{m})$ compared to the first procedure $(\sim 15.7 \mu \mathrm{m})$ (Fig. 7). (In both cases the diameter is $1.1 \mu \mathrm{m}$.) Such a decrease might be attributable to the solubilisation of $\mathrm{Zn}(\mathrm{OH})_{4}{ }^{2-}$ species as a result of the prolonged aging $(20 \mathrm{~h})$ in the basic solution $(\mathrm{pH}>9)$. It should be noted that factors such as the free volume in the vessel and the oxygen partial pressure in the vessel may also play important roles.

\section{Effect of counterions}

Reactions with different zinc precursors such as zinc acetate, zinc chloride and zinc sulfate have also been carried out to investigate and compare the effect of counterions on the micro-javelin formation. Zinc acetate gave multidisperse $\mathrm{ZnO}$ half-javelins of $\sim 4 \mu \mathrm{m}$ length (Fig. 8a). Zinc chloride produced $\mathrm{ZnO}$ microjavelins of $18 \pm 2 \mu \mathrm{m}$ length (Fig. 8c). Zinc sulfate on the other hand produced mostly agglomerated particles with some halfjavelins (Fig. 8e). Corresponding XRD patterns indicated the formation of crystalline wurtzite $\mathrm{ZnO}$ by both acetate and chloride routes (Fig. 8b and d), while the sulfate route (Fig. 8f) gave a mixture of zinc carbonate and $\mathrm{ZnO}$ peaks but with lower intensity. The comparatively higher complexing ability of acetate may be the reason behind the poor formation of $\mathrm{ZnO}$ micro-javelins from $\mathrm{Zn}(\mathrm{OAc})_{2}{ }^{46}$ compared to the counterions such as $\mathrm{Cl}^{-}$and $\mathrm{NO}_{3}{ }^{2-}$, which have less significant influence on the nucleation and growth of the metal carbonate and oxide particles.

\section{Effect of urea/ammonium carbamate}

In order to investigate the role of urea hydrolysis products, experiments were conducted with $100 \mathrm{mM}$ ammonium carbamate (instead of urea) and $10 \mathrm{mM}$ zinc nitrate solution for 20 min. Interestingly, a wire-like particle morphology was observed in the SEM (Fig. 9). The wires were found to be composed of $\mathrm{Zn}_{4} \mathrm{CO}_{3}(\mathrm{OH})_{6} \cdot \mathrm{H}_{2} \mathrm{O}$ rather than $\mathrm{ZnO}$ particles. On calcination to $500{ }^{\circ} \mathrm{C}$ the particles were converted to $\mathrm{ZnO}$ with capsule like morphology (ESI $\dagger 5)$. This experiment suggests that carbamate ions are less likely to play a major role in the formation of the micro-javelins.

\section{Photoluminescence of $\mathrm{ZnO}$ micro-javelins}

Fig. 10 presents the room temperature $\mathrm{PL}$ spectra of $\mathrm{ZnO}$ particles obtained after 13, 18 and $24 \mathrm{~min}$ of MW irradiation. All the spectra show a near band edge emission at $\sim 3.2 \mathrm{eV}$. . $^{-50}$ Further, an enhancement in intensity of the $390 \mathrm{~nm}$ band can be observed with increasing MW irradiation time. The defect luminescence band in the green region, which is the case for most of the reported $\mathrm{ZnO}$ particles, ${ }^{51}$ could not, however, be observed in the present samples. This method could therefore be assumed as giving reasonably defect-free $\mathrm{ZnO}$ particles that could have wide technological implications in LEDs, lasers and transparent transistors. ${ }^{52}$

\section{Discussion}

Highly crystalline, monodisperse $\mathrm{ZnO}$ micro-javelins with dominant (1000) diffraction have been obtained by a one-step $\mathrm{MW}$-assisted synthesis procedure. An investigation on the effect of $\mathrm{pH}, \mathrm{Zn}^{2+}$ ion concentration and time of $\mathrm{MW}$ irradiation reveals the structural evolution of javelins. XRD of the $13 \mathrm{~min}$ irradiated sample showed the diffractions corresponding to a mixture of small fractions of $\mathrm{ZnO}$ and $\mathrm{Zn}_{5}\left(\mathrm{CO}_{3}\right)_{2}(\mathrm{OH})_{6}(\mathbf{1})^{42}$ while all the other samples (irradiated for longer time) produced wurtzite $\mathrm{ZnO}$. The intermediate zinc carbonate compound (1) and $\mathrm{ZnO}$ nuclei are precipitated as a consequence of the $\mathrm{MW}$ induced supersaturation of soluble zinc species and the release of species such as $\mathrm{HCO}_{3}{ }^{-}$and $\mathrm{NH}_{3}$ into the solution. On continuing the irradiation further, the intermediate carbonate compound redissolves/dissociates and the growth units are formed in turn, which then add onto the existing $\mathrm{ZnO}$ nuclei to form the javelins. Urea being a comparatively neutral hydrolysis medium also favours the elongated prismatic growth of $\mathrm{ZnO}$ particles probably due to its comparatively weak complexing ability to the $\mathrm{Zn}^{2+}$ species. In comparison, alkaline $\mathrm{NaOH}$ and other strong complexing agents are reported to suppress the axial growth of $\mathrm{ZnO}$ 

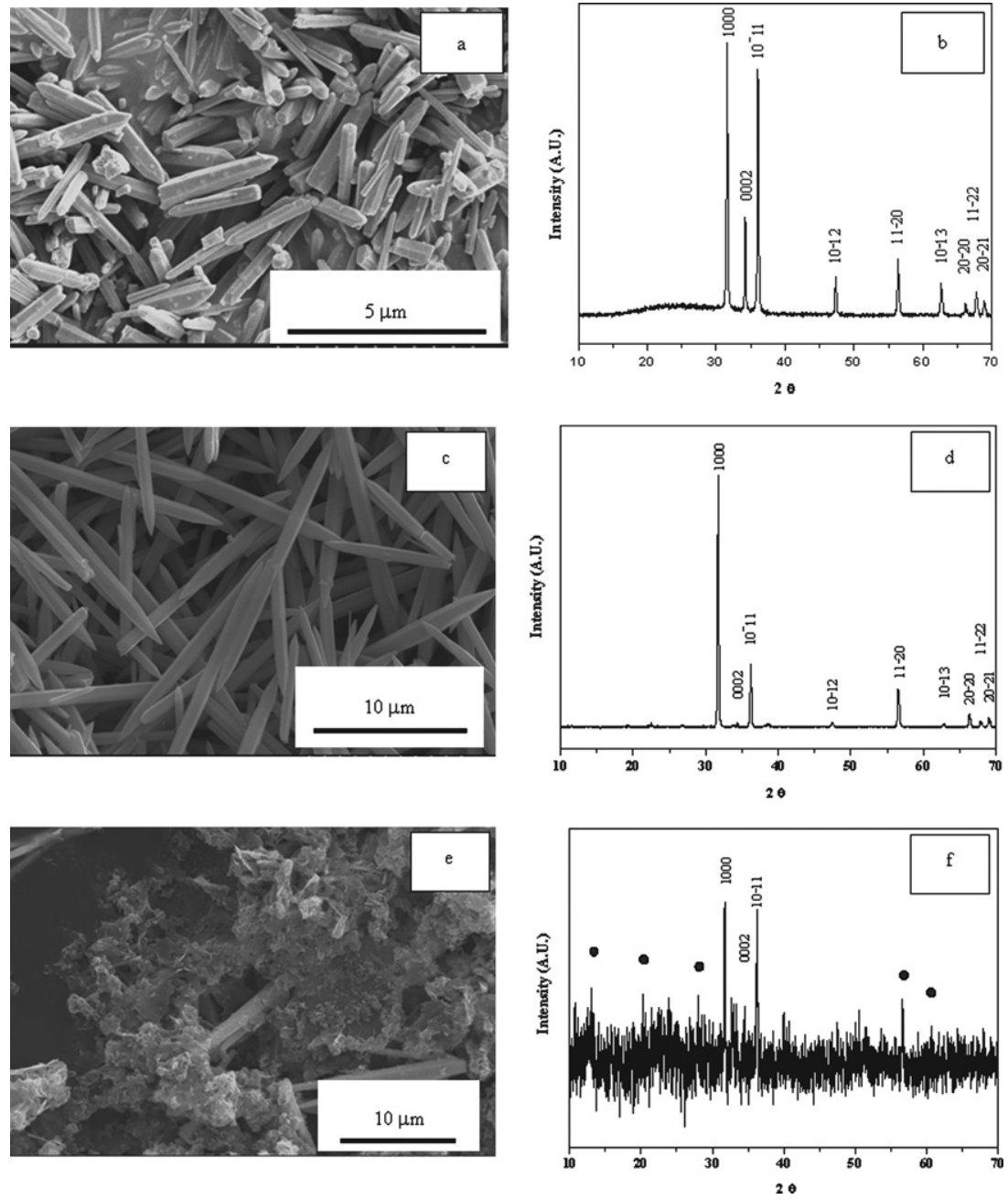

Fig. 8 (a) FESEM and (b) XRD of sample prepared by the zinc acetate and urea at $150 \mathrm{~W}$ for $20 \mathrm{~min}$. (c) FESEM and (d) XRD of sample prepared by the zinc chloride and urea at $150 \mathrm{~W}$ for $20 \mathrm{~min}$. (e) FESEM and (f) XRD of sample prepared by the zinc sulfate and urea at $150 \mathrm{~W}$ for $20 \mathrm{~min}$. $\mathrm{Zn}_{5}\left(\mathrm{CO}_{3}\right)_{2}(\mathrm{OH})_{6}(\mathbf{1})$.

particles by strongly complexing with the surface $\mathrm{Zn}^{2+}$ ions in the (0001) face. ${ }^{53}$

The SEM experiments clearly demonstrate the change of shape as the experiment proceeds. Thus the 11 and 12 min irradiated samples show amorphous precipitates with flaky plate-like morphology, whereas in the 13 min sample rod-like particles are present. $\mathrm{ZnO}$ micro-javelins were already present in the $14 \mathrm{~min}$ irradiated sample and this structure was found to be retained on further irradiation up to $24 \mathrm{~min}$. Further, it may be noted that samples prepared by irradiating the solution for $>17 \mathrm{~min}$ showed an interesting etching behaviour through the middle portion of the micro-javelins (Fig. 6). This indicates the possibility of the presence of a zinc-rich region towards the middle of the micro-javelins.

\section{Growth mechanism}

It is essential to know the structural habit of $\mathrm{ZnO}$ to understand the growth mechanism. The structure of $\mathrm{ZnO}$ can be described as consisting of hexagonal close packing of oxygen and zinc atoms in space group $P 6_{3} m c$ with oxygen atoms bonded to zinc atoms occupied in tetrahedral sites. ${ }^{54}$ The zinc and oxygen atoms are alternately arranged along the $c$-axis of the hexagonal phase. The structure has no centre of inversion, and this anisotropy provides an inherent polarity to the crystal along the $c$-axis.

The (0001) plane (terminated with $\mathrm{Zn}^{2+}$ ions) of $\mathrm{ZnO}$ has the maximum surface energy, while the $(000-1)$ plane (terminated with $\mathrm{O}^{2-}$ ions) has the minimum surface energy. The faces with the moderate growth velocities are $\mathrm{V}_{\{\overline{1} 01 \overline{1}\}}>\mathrm{V}_{\{\overline{1} 010\}}>\mathrm{V}_{\{\overline{1} 011\}} \cdot{ }^{54}$ Schematic presented in Fig. 11 shows various faces of a typical javelin-like $\mathrm{ZnO}$ particle.

The formation of bridged $\mathrm{ZnO}$ structures has been previously observed. ${ }^{33,34,55}$ Oliveira et $a l .{ }^{33}$ and Xie et al. ${ }^{34}$ proposed a germination of the second half from the base of a preformed half-ellipsoid as the mechanism of ellipsoid formation. Further, it has been shown in several examples that the decomposition of urea in aqueous solutions at elevated temperatures can be utilised to produce colloidal dispersions consisting of uniform particles. ${ }^{56}$ The influence of zinc counterions on the shape evolution has also been reported. ${ }^{18}$ Literature on the $\mathrm{pH}$ dependence of $\mathrm{ZnO}$ and $\mathrm{Zn}(\mathrm{OH})_{2}$ formation is also available. ${ }^{43}$ However, to the best of our knowledge, the mechanism underlying the formation of $\mathrm{ZnO}$ 

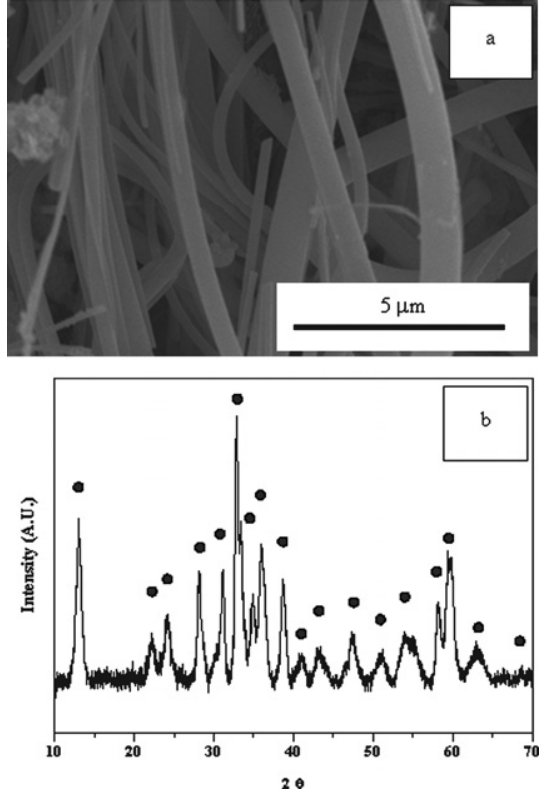

Fig. 9 (a) SEM and (b) XRD of sample prepared from zinc nitrate and ammonium carbamate. $-\mathrm{Zn}_{5}\left(\mathrm{CO}_{3}\right)_{2}(\mathrm{OH})_{6}$.

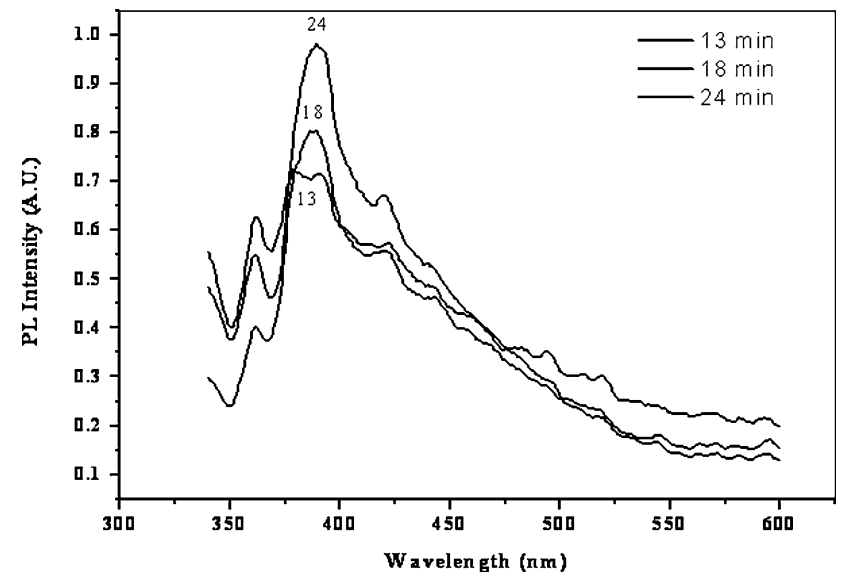

Fig. 10 Room temperature PL spectra of $\mathrm{ZnO}$ particles obtained by different time of MW irradiation, suspended in 2:1 ethylene glycol:water mixture. (Excitation at $325 \mathrm{~nm}$.)

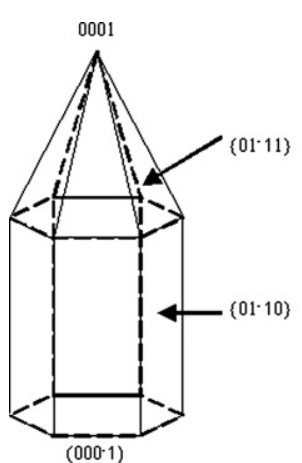

(a)

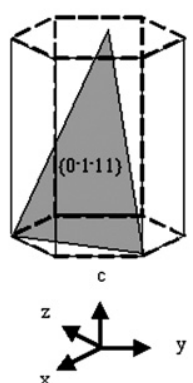

(b)

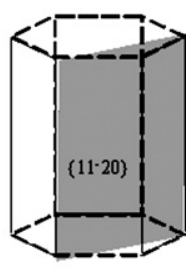

(c)
Fig. 11 Schematic showing various faces of the hexagonal $\mathrm{ZnO}$ particle:

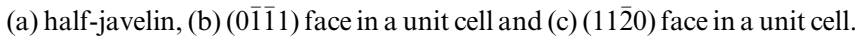

micro-javelins under the restricted $\mathrm{pH}$ condition has not been reported previously.

In much of the literature presenting hydrothermal synthesis of $\mathrm{ZnO}, \mathrm{Zn}(\mathrm{OH})_{4}{ }^{2-}$ was reported as the growth unit for the formation of wurtzite $\mathrm{ZnO} .{ }^{57,58}$ However, in the present rapid microwave process in the presence of urea, where the $\mathrm{pH}$ of the solution is found to be restricted to $<10, \mathrm{Zn}^{2+}, \mathrm{Zn}(\mathrm{OH})^{+}$and $\mathrm{Zn}(\mathrm{OH})_{2}$ could be the possible zinc species $^{43,59}$ with highest supersaturation. Hence the growth process may be different. Indeed, the micro-javelins are formed rapidly under weakly basic conditions ( $\mathrm{pH} 7-7.5$ ) by the present microwave process.

In the present case, it is likely that a number of molecular species influence this reaction. It is known that upon heating urea breaks down to form initially carbamate and ammonia. Subsequent reaction leads to carbonate/bicarbonate formation. ${ }^{60}$ As a result of the formation of these species the $\mathrm{pH}$ rises as is indeed observed during our experiments.

$$
\begin{gathered}
\mathrm{NH}_{2} \mathrm{CONH}_{2}+\mathrm{H}_{2} \mathrm{O} \rightarrow \mathrm{NH}_{2} \mathrm{CO}_{2}{ }^{-}+\mathrm{NH}_{4}^{+} \\
\mathrm{NH}_{2} \mathrm{CO}_{2}{ }^{-}+\mathrm{H}_{2} \mathrm{O} \rightarrow \mathrm{NH}_{4}^{+}+\mathrm{CO}_{3}{ }^{2-}
\end{gathered}
$$

$$
\begin{gathered}
\mathrm{NH}_{4}^{+} \rightleftharpoons \mathrm{NH}_{3}+\mathrm{H}^{+}, \mathrm{p} K_{\mathrm{a}}=9.24 \\
\mathrm{NH}_{2} \mathrm{CO}_{2} \mathrm{H} \rightleftharpoons \mathrm{NH}_{2} \mathrm{CO}_{2}^{-}+\mathrm{H}^{+}, \mathrm{p} K_{\mathrm{a}}=5.8 \\
\mathrm{H}_{2} \mathrm{CO}_{3} \rightleftharpoons \mathrm{HCO}_{3}{ }^{-}+\mathrm{H}^{+}, \mathrm{p} K_{\mathrm{a}}=6.4 \\
\mathrm{HCO}_{3}{ }^{-} \rightleftharpoons \mathrm{CO}_{3}{ }^{2-}+\mathrm{H}^{+}, \mathrm{p} K_{\mathrm{a}}=10.3
\end{gathered}
$$

Additionally, under our reaction conditions the ammonia may complex with zinc ions

$$
\mathrm{Zn}^{2+}+n \mathrm{NH}_{3(\mathrm{aq})} \rightleftharpoons \mathrm{Zn}\left(\mathrm{NH}_{3}\right)_{n}{ }^{2+}
$$

In our process the solid forming initially (e.g. at $11 \mathrm{~min}$ ) contains a large amount of $\mathrm{Zn}_{5}\left(\mathrm{CO}_{3}\right)_{2}(\mathrm{OH})_{6}$ (1). However, at times $>14 \mathrm{~min} \mathrm{ZnO}$ is the only solid species identified. It may be noted that 1 decomposes at temperature $>150{ }^{\circ} \mathrm{C}$. This may occur in our case or alternatively $\mathbf{1}$ may redissolve. We favour the redissolution of $\mathbf{1}$ as this should happen with the increase in $\mathrm{NH}_{3}$ concentration. The formation of $\mathrm{ZnO}$ is consistent with the increase in $\mathrm{pH}$ at longer time.

Fig. 12 presents a schematic of the events happening in the growth of $\mathrm{ZnO}$ micro-javelins. In the case of the 11-12 min samples the growth of nuclei is inhibited possibly by its coordination with the $\mathrm{NH}_{2} \mathrm{COO}^{-}$species produced as a result of the decomposition of urea. Further irradiation induces the decomposition of $\mathrm{NH}_{2} \mathrm{COO}^{-}$species into $\mathrm{NH}_{4}^{+}$and $\mathrm{CO}_{3}{ }^{2-}$ species, which results in the formation of thermodynamically stable $\mathrm{Zn}_{5}\left(\mathrm{CO}_{3}\right)_{2}(\mathrm{OH})_{6}$ particles (ESI $\dagger$ 2). ${ }^{61}$ The hydrozincite (1) particles, however, are found to be unstable in 


\section{坥三

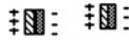 \\ 夆速三 辛国三}

(a)

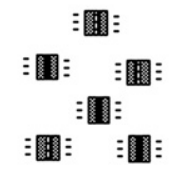

(c)

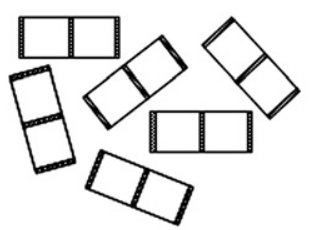

(e)

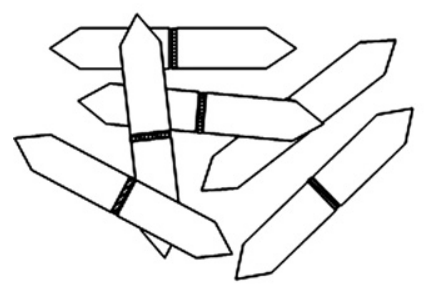

(g)

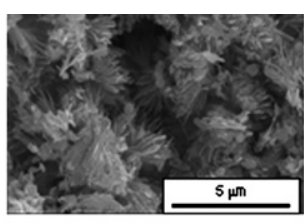

(b)

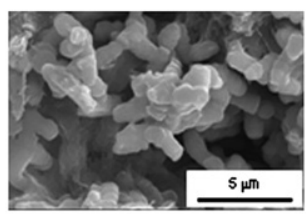

(d)

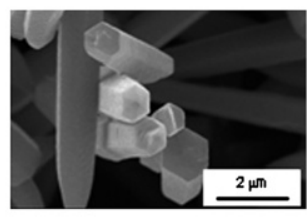

(f)

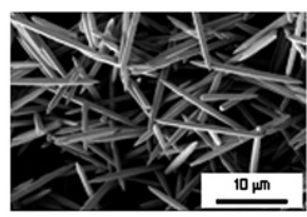

(h)
1] - zinc-rich face and - oxygen-rich face

Fig. 12 Schematic showing the sequential processes occurring in the $\mathrm{ZnO}$ javelin formation. 11-12 min irradiated samples (particles with a flaky shape) are saturated with urea-complexed $\mathrm{Zn}^{2+}$ species [nuclei having urea coordination $\left(\mathrm{NH}_{2} \mathrm{COO}^{-}\right)$at the $\mathrm{Zn}$-rich face (a) and (b)] $13 \mathrm{~min}$ of irradiation induces an initial growth through the oxygen-rich face by the deposition of $\mathrm{Zn}(\mathrm{OH})^{+}$species [linking of particles (c) and (d)] On further irradiation, the deposition of $\mathrm{Zn}(\mathrm{OH})_{2}$ occurs by dehydration with surface $\mathrm{Zn}-\mathrm{OH}[(\mathrm{e})$ and (f)] and javelins are formed subsequently $[\geq 14 \min (\mathrm{g})$ and $(\mathrm{h})]$.

the presence of ammonia, which is being generated subsequently. The dissolution of hydrozincite particles (1) occurs as a result and the formed $\mathrm{Zn}(\mathrm{OH})^{+}$species subsequently add onto the oxygen-rich face of the nuclei (linking of particles). ${ }^{19,43,62}$ This results in the formation of a spherical- to rod-like kind of morphology.

According to the phase stability diagrams for the $\mathrm{ZnO}-\mathrm{H}_{2} \mathrm{O}$ and $\mathrm{Zn}(\mathrm{OH})_{2}-\mathrm{H}_{2} \mathrm{O}$ systems at $25^{\circ} \mathrm{C}$ and thermodynamic data (ESI $\dagger 6)$ presented in ref. 43 , the soluble species such as $\mathrm{Zn}^{2+}$ and $\mathrm{ZnOH}^{+}$are stable below $\mathrm{pH} \approx 7$ at a $\mathrm{Zn}^{2+}$ concentration of $5 \mathrm{mM}$. These diagrams also indicate that the solubility of $\mathrm{ZnO}$ is almost the same as that of $\mathrm{Zn}(\mathrm{OH})_{2}$. Thus, both $\mathrm{Zn}(\mathrm{OH})_{2}$ and $\mathrm{ZnO}$ should be thermodynamically stable over a $\mathrm{pH}$ range of 8 to 12 at a $5 \mathrm{mM} \mathrm{Zn}^{2+}$ concentration. The wurtzite $\mathrm{ZnO}$ particles are, however, observed, in the present case, at the $\mathrm{pH}$ range 7.04-9.75 and are consistent with the phase stability diagram. This selective crystallisation and growth of wurtzite $\mathrm{ZnO}$ particles could also be attributed to the presence of existing $\mathrm{ZnO}$ nuclei, which act as heterogeneous nucleation sites.

Castellano and Matijevic previously reported the formation of rod shaped basic zinc carbonate (hydrozincite) particles from aqueous solutions of zinc nitrate and urea at elevated temperatures $\left(90^{\circ} \mathrm{C}\right)$ and its subsequent transformation to $\mathrm{ZnO}$ rods on calcination. ${ }^{63}$ Our experiments resulted in the formation of a mixture of zinc carbonate and $\mathrm{ZnO}$ structures at the initial stages of MW irradiation. With increasing irradiation time, the $\mathrm{ZnO}$ particles are grown through an intermediate amorphous $\mathrm{Zn}(\mathrm{OH})_{2}$ pathway. Such a reaction sequence also corroborates with a previous observation by McBride et al., where the formation of intermediate $\mathrm{Zn}(\mathrm{OH})_{2}$ has been suggested as a prerequisite for the controlled growth of $\mathrm{ZnO}$ needles. ${ }^{16}$ However, X-ray diffractions corresponding to $\mathrm{Zn}(\mathrm{OH})_{2}$ could not be observed in any of our low irradiation time samples. In light of all these factors, it is proposed that the $\mathrm{ZnO}$ javelin growth occurs through a different pathway under the conditions of the effective and rapid homogeneous heating of the microwave process. Based on our experimental results and the previous reports ${ }^{25,43,57,64,65}$ the growth process can be explained as follows. The high supersaturation of $\mathrm{Zn}^{2+}$ species at the initial stage (under the neutral $\mathrm{pH}$ condition) of the $\mathrm{MW}$ irradiation of zinc nitrate and excess urea (10 times) results in the precipitation of $\mathrm{Zn}_{5}\left(\mathrm{CO}_{3}\right)_{2}(\mathrm{OH})_{6}$ and $\mathrm{ZnO}$ nuclei according to the reaction:

$$
\begin{gathered}
5 \mathrm{Zn}^{2+}+2 \mathrm{CO}_{3}{ }^{2-}+6 \mathrm{OH}^{-} \rightleftharpoons \mathrm{Zn}_{5}\left(\mathrm{CO}_{3}\right)_{2}(\mathrm{OH})_{6(\mathrm{~s})} \\
\mathrm{Zn}^{2+}+\mathrm{H}_{2} \mathrm{O} \rightleftharpoons \mathrm{ZnO}_{(\mathrm{s})}+2 \mathrm{H}^{+}
\end{gathered}
$$

Further irradiation results in the building up of $\mathrm{NH}_{3}$ in the solution. Under such weakly alkaline condition, $\mathrm{Zn}^{2+}$ cations form ammine complexes of $\mathrm{Zn}\left(\mathrm{NH}_{3}\right)_{n}{ }^{2+}$ as in eqn (3). The ammine complex formation shifts the equilibrium in reaction (4) to the left. This in turn results in the supersaturation of species such as $\mathrm{Zn}(\mathrm{OH})^{+}$and $\mathrm{Zn}(\mathrm{OH})_{2}$ in the solution according to the reaction:

$$
\begin{aligned}
& \mathrm{Zn}^{2+}+\mathrm{OH}^{-} \rightleftharpoons \mathrm{Zn}(\mathrm{OH})^{+} \\
& \mathrm{Zn}^{2+}+2 \mathrm{OH}^{-} \rightleftharpoons \mathrm{Zn}(\mathrm{OH})_{2}
\end{aligned}
$$

All these sequential reactions are consistent with the $\mathrm{p} K_{\mathrm{a}}$ values. This sequential formation of $\mathrm{Zn}(\mathrm{OH})^{+}$under the weakly alkaline condition appears to be the key step that initiates the formation of javelin-like particles in the present system. The addition of $\mathrm{Zn}(\mathrm{OH})^{+}$species onto the oxygen-rich $(000-1)$ face of the existing $\mathrm{ZnO}$ nuclei results in the formation of a structure which is rich in $\mathrm{Zn}^{2+}$ species on both the ends of the particles (Fig. 12c). Subsequently, javelins are formed by the dehydration reaction between the surface hydroxide species (either end) and the $\mathrm{OH}^{-}$species on the zinc complexes according to reaction:

$\mathrm{Zn}^{2+}-\mathrm{OH}_{\text {(surface) }}+\mathrm{Zn}(\mathrm{OH})_{2(\text { aq })} \rightleftharpoons \mathrm{Zn}_{2} \mathrm{O}(\mathrm{OH})_{\text {(surface) }}+\mathrm{H}_{2} \mathrm{O}(8)$

The structural fit between the phases favours the heterogeneous nucleation of the supersaturated $\mathrm{Zn}(\mathrm{OH})_{2}$ species to the $\mathrm{ZnO}$ nuclei rather than the bulk homogeneous nucleation and growth of $\mathrm{ZnO}$ nuclei. ${ }^{43,65}$ Further, it can be observed that the micro-javelins form at a moderately alkaline $\mathrm{pH}$ (sample 5 in 
Table 1). Hence, the supersaturation of species such as $\mathrm{Zn}(\mathrm{OH})^{+}$ and $\mathrm{Zn}(\mathrm{OH})_{2}$ should be the defining factors here for microjavelins growth. The ammine complexation does not seem to have a strong influence on the micro-javelin formation, due to the lower $\mathrm{NH}_{4}{ }^{+}$to $\mathrm{Zn}^{2+}$ ratio in the present case, as previously reported by Yamabi and Imai. ${ }^{43}$ However, it plays a key role in the dissolution of the initially formed hydrozincite particles. Further, the $\mathrm{pH}$ dependent bicarbonate-carbonate equilibria $(\mathrm{ESI} \uparrow 7)$ indicate bicarbonate as the predominant species in the pH range 8-10, which is consistent with the FTIR results.

The present microwave-assisted process resulted in the formation of highly crystalline monodispersed micro-javelins with significantly larger sizes $(\sim 15 \pm 2 \mu \mathrm{m}$ length $v s . \sim 1 \mu \mathrm{m}$ width) compared to the previous reports. ${ }^{66}$ This could possibly be attributed to the rapid homogeneous heating of the MW process, which leads to a greater extent of supersaturation of $\mathrm{ZnO}$ and thus results in a small number of $\mathrm{ZnO}$ nuclei. The growth onto these limited numbers of nuclei therefore results in larger particles. Indeed, the unusual XRD pattern shown by the particles is attributed to such a high aspect ratio, which when placed in a glass plate (substrate used for XRD) tends to align themselves with their $c$-axis parallel to the substrate. Such an arrangement enhances the probability for most of their (1000) planes to come against the X-ray beam, compared to any other planes, hence giving a high intensity peak.

The optical studies of the micro-javelins showed only a weak PL emission. However, the striking observation was the absence of green light defect luminescence. This can be attributed to relatively low amounts of surface defects for the longer time irradiated samples. The present method is therefore found to be effective in producing reasonably defect-free $\mathrm{ZnO}$ particles.

\section{Conclusions}

In summary, a straightforward one-step microwave reaction between zinc nitrate and urea in aqueous solutions produced highly crystalline wurtzite $\mathrm{ZnO}$ micro-javelins with a predominant (1000) X-ray diffraction. The javelins have, however, been found to grow in the (0001) direction and the appearance of the extremely dominant (1000) X-ray diffraction peak is attributed to their high aspect ratio. The growth is proposed to involve the MW induced precipitation of $\mathrm{ZnO}$ nuclei and metastable zinc carbonate structures along with the release of species such as $\mathrm{NH}_{2} \mathrm{COO}^{-}, \mathrm{HCO}_{3}{ }^{-}$and ammonia into the solution. Upon continued irradiation, the dissolution of the intermediate carbonate structures results in the formation of species such as $\mathrm{Zn}(\mathrm{OH})^{+}$and $\mathrm{Zn}(\mathrm{OH})_{2}$ and the addition of $\mathrm{Zn}(\mathrm{OH})^{+}$onto the oxygen-rich face of the existing $\mathrm{ZnO}$ nuclei occurs to form rodlike kind of particles having an outermost $\mathrm{Zn}^{2+}$ layer at both its ends. Such particles then grow to form the micro-javelins by a heterogeneous nucleation-assisted growth between them and the $\mathrm{Zn}(\mathrm{OH})_{2}$ species. The consumption of $\mathrm{NH}_{2} \mathrm{COO}^{-}$species upon extensive irradiation results in the elimination of the growth barrier that in turn dictates the tapering of both the ends of the particles to form pointed tips, hence micro-javelins.

The microwave induced supersaturation of $\mathrm{Zn}^{2+}$ and $\mathrm{Zn}(\mathrm{OH})^{+}$ species under the moderately basic $\mathrm{pH}$ condition, and the resultant initial growth through the oxygen terminated $(000 \overline{1})$ facet, have been identified as the key steps responsible for the formation of micro-javelins. An enhanced UV emission was shown by such perfectly grown $\mathrm{ZnO}$ javelins with reasonably low green luminescence. Furthermore, the method does not involve any complex additives, surfactants or polymeric agents. Wellcrystallised products are formed in a single-step process without the need for special separation procedures. This straightforward method can therefore be used for the preparation of reasonably defect-free $\mathrm{ZnO}$ micro-javelins in a cost-effective way.

\section{Acknowledgements}

SCP acknowledges the financial support of IRCSET Postdoctoral Fellowship programme. Dedicated to Dr K. G. K. Warrier on the occasion of his retirement.

\section{Notes and references}

1 M. Afzaal, M. A. Malik and P. O’Brien, New J. Chem., 2007, 31, 2029; J. L. Yang, S. J. An, W. I. Park, G. C. Yi and W. Choi, Adv. Mater., 2004, 16, 1661.

2 Z. P. Sun, L. Liu, L. Zhang and D. Z. Jia, Nanotechnology, 2006, 17, 2266.

3 H. Y. Yang, S. P. Lau, S. F. Yu, A. P. Abiyasa, M. Tanemura, T. Okita and H. Hatano, Appl. Phys. Lett., 2006, 89, 011103.

4 Y. Nakanishi, A. Miyake, H. Kominami, T. Aoki, Y. Hatanaka and G. Shimaoka, Appl. Surf. Sci., 1999, 142, 233.

5 K. C. Hui, C. W. Lai and H. C. Ong, Thin Solid Films, 2005, 483, 222.

6 S. C. Pillai, J. M. Kelly, D. E. McCormack, P. O'Brien and R. Ramesh, J. Mater. Chem., 2003, 13, 2586; S. C. Pillai, J. M. Kelly, D. E. McCormack and R. Ramesh, J. Mater. Chem., 2004, 14, 1572; S. C. Pillai, J. M. Kelly, D. E. McCormack and R. Ramesh, Adv. Appl. Ceram., 2006, 105, 158.

7 B. P. Zhang, N. T. Binh, Y. Segawa, K. Wakatsuki and N. Usami, Appl. Phys. Lett., 2003, 83, 1635.

8 J. Zhang, L. D. Sun, C. S. Liao and C. H. Yan, Chem. Commun., 2002, 262.

9 J. H. Song, J. Zhou and Z. L. Wang, Nano Lett., 2006, 6, 1656.

10 F. Li, Y. Ding, P. X. X. Gao, X. Q. Xin and Z. L. Wang, Angew. Chem., Int. Ed., 2004, 43, 5238.

11 Z. L. Wang, J. Phys.: Condens. Matter, 2004, 16, R829; L. Guo and Y. L. Ji, J. Am. Chem. Soc., 2002, 124, 14864; S. Kar, A. Dev, S. Chakrabarty and S. Chaudhuri, J. Phys. Chem. B, 2006, 110, 17848.

12 D. S. Boyle, K. Govender and P. O'Brien, Chem. Commun., 2002, 80.

13 L. Vayssieres, Adv. Mater., 2003, 15, 464.

14 S. C. Kashyap, J. Appl. Phys., 1973, 44, 4381.

15 T. Sekiguchi, S. Miyashita, K. Obara, T. Shishido and N. Sakagami, J. Cryst. Growth, 2000, 214, 72.

16 R. A. McBride, J. M. Kelly and D. E. McCormack, J. Mater. Chem., 2003, 13, 1196; B. Liu and H. C. Zeng, J. Am. Chem. Soc., 2003, 125, 4430.

17 B. Cheng and E. T. Samulski, Chem. Commun., 2004, 986.

18 K. Govender, D. S. Boyle, P. B. Kenway and P. O'Brien, J. Mater. Chem., 2004, 14, 2575.

19 Q. Zhong and E. Matijevic, J. Mater. Chem., 1996, 6, 443; W. Peng, S. Qu, G. Cong and Z. Wang, Cryst. Growth Des., 2006, 6, 1518; B. Liu and H. C. Zeng, J. Am. Chem. Soc., 2003, 125, 4430.

20 G. G. Valle, P. Hammer, S. H. Pulcinelli and C. V. Santilli, J. Eur. Ceram. Soc., 2004, 24, 1009.

21 L. Dong, Y. C. Liu, Y. H. Tong, Z. Y. Xiao, J. Y. Zhang, Y. M. Lu, D. Z. Shen and X. W. Fan, J. Colloid Interface Sci., 2005, 283, 380.

22 M. Oner, J. Norwig, W. H. Meyer and G. Wegner, Chem. Mater., 1998, 10, 460.

23 P. Li, Y. Wei, H. Liu and X. Wang, Chem. Commun., 2004, 2856.

24 Z. Q. Li, Y. J. Xiong and Y. Xie, Inorg. Chem., 2003, 42, 8105.

25 H. Zhang, D. R. Yang, D. S. Li, X. Y. Ma, S. Z. Li and D. L. Que, Cryst. Growth Des., 2005, 5, 547.

26 X. M. Sui, Y. C. Liu, C. L. Shao, Y. X. Liu and C. S. Xu, Chem. Phys. Lett., 2006, 424, 340.

27 J. Zhang, L. D. Sun, H. Y. Pan, C. S. Liao and C. H. Yan, New J. Chem., 2002, 26, 33. 
28 D. Kaneko, H. Shouji, T. Kawai and K. Kon-No, Langmuir, 2000, 16, 4086.

29 E. Tsuchida and S. Kitajima, Chem. Lett., 1990, 1769.

30 D. Ledwith, S. C. Pillai, G. W. Watson and J. M. Kelly, Chem. Commun., 2004, 2294.

31 S. A. Galema, Chem. Soc. Rev., 1997, 26, 233; C. C. Landry and A. R. Barron, Science, 1993, 260, 1653.

32 R. Harpeness and A. Gedanken, New J. Chem., 2003, 27, 1991; R. Harpeness, A. Gedanken, A. M. Weiss and M. A. Slifkin, J. Mater. Chem., 2003, 13, 2603.

33 P. A. Oliveira, J. F. Hochepied, F. Grillon and M. H. Berger, Chem. Mater., 2003, 15, 3202.

34 R. Xie, D. Li, H. Zhang, D. Yang, M. Jiang, T. Sekiguchi, B. Liu and Y. Bando, J. Phys. Chem. B, 2006, 110, 19147; X. L. Hu, Y. J. Zhu and S. W. Wang, Mater. Chem. Phys., 2004, 88, 421; J. Liang, J. Liu, Q. Xie, S. Bai, W. Yu and Y. Qian, J. Phys. Chem. B, 2005, 109, 9463.

35 S. Music, D. Dragcevic, M. Maljkovic and S. Popovic, Mater. Chem. Phys., 2003, 77, 521.

36 M. A. Verges, A. Mifsud and C. J. Serna, J. Chem. Soc., Faraday Trans., 1990, 86, 959.

37 D. Stoilova, V. Koleva and V. Vassileva, Spectrochim. Acta, Part A, 2002, 58, 2051.

38 K. Kakiuchi, E. Hosono, T. Kimura, H. Imai and S. Fujihara, J. Sol-Gel Sci. Technol., 2006, 39, 63.

39 C. P. Sibu, S. R. Kumar, P. Mukundan and K. G. K. Warrier, Chem. Mater., 2002, 14, 2876.

40 G. Xiong, U. Pal and G. Serrano, J. Appl. Phys., 2007, 101, 024317.

41 N. Kanari, D. Mishra, I. Gaballah and B. Dupre, Thermochim. Acta, 2004, 410, 93.

42 S. Du, Y. Tian, J. Liu, H. Liu and Y. Chen, Mater. Lett., 2006, 60, 3133

43 S. Yamabi and H. Imai, J. Mater. Chem., 2002, 12, 3773; R. A. Reichle, K. G. McCurdy and L. G. Hepler, Can. J. Chem., 1975, 53, 3841; J. Zhao, Z. G. Jin, X. X. Liu and Z. F. Liu, J. Eur. Ceram. Soc., 2006, 26, 3745; W. Stumm and J. J. Morgan, Aquatic Chemistry, Wiley-Interscience, New York, 1995, p. 1002.

44 S. Komarneni, M. Bruno and E. Mariani, Mater. Res. Bull., 2000, 35, 1843.

45 D. Kisailus, B. Schwenzer, J. Gomm, J. C. Weaver and D. E. Morse, J. Am. Chem. Soc., 2006, 128, 10276.

46 J. S. Bendall, G. Visimberga, M. Szachowicz, N. O. V. Plank, S. Romanov, C. M. Sotomayor-Torres and M. E. Welland, J. Mater. Chem., 2008, 18, 5259; T. R. Zhang, W. J. Dong, M. Keeter-Brewer, S. Konar, R. N. Njabon and Z. R. Tian, J. Am. Chem. Soc., 2006, 128, 10960.

47 H. Yan, R. He, J. Pham and P. Yang, Adv. Mater., 2003, 15, 402.

48 D. W. Bahnemann, C. Kormann and M. R. Hoffmann, J. Phys. Chem., 1987, 91, 3789.

49 Y. S. Wang, P. J. Thomas and P. O'Brien, J. Phys. Chem. B, 2006, 110, 4099; T. Andelman, Y. Gong, M. Polking, M. Yin, I. Kuskovsky, G. Neumark and S. O'Brien, J. Phys. Chem. B, 2005,
109, 14314; Y. Chen, M. Kim, G. Lian, M. B. Johnson and X. Peng, J. Am. Chem. Soc., 2005, 127, 13331; N. S. Norberg and D. R. Gamelin, J. Phys. Chem. B, 2005, 109, 20810.

50 N. Takahashi, M. Makino, T. Nakamura and H. Yamamoto, Chem. Mater., 2002, 14, 3622; N. Kumar, A. Dorfman and J. Hahm, J. Nanosci. Nanotechnol., 2005, 5, 1915.

51 C. A. Arguello, D. L. Rousseau and S. P. S. Porto, Phys. Rev., 1969, 181, 1351 .

52 A. K. Arora and Kamaluddin, Colloids Surf., A: Physicochemical and Engineering Aspects, 2007, 298, 186.

53 Y. Y. Zhang and J. Mu, Nanotechnology, 2007, 18, 075606.

54 W. J. Li, E. W. Shi, W. Z. Zhong and Z. W. Yin, J. Cryst. Growth, 1999, 203, 186; L. Vayssieres, K. Keis, A. Hagfeldt and S.-E. Lindquist, Chem. Mater., 2001, 13, 4395; A. Wander, F. Schedin, P. Steadman, A. Norris, R. McGrath, T. S. Turner, G. Thornton and N. M. Harrison, Phys. Rev. Lett., 2001, 86, 3811; F. Claeyssens, C. L. Freeman, N. L. Allan, Y. Sun, M. N. R. Ashfold and J. H. Harding, J. Mater. Chem., 2005, 15, 139.

55 S. Cho, J.-W. Jang, S.-H. Jung, B. R. Lee, E. Oh and K.-H. Lee, Langmuir, 2009, 25, 3825.

56 H. Qian, G. Lin, Y. Zhang, P. Gunawan and R. Xu, Nanotechnology, 2007, 18, 355602/1; K. Ito and K. Nakamura, Thin Solid Films, 1996, 286, 35 .

57 J. Wang and L. Gao, J. Mater. Chem., 2003, 13, 2551.

58 R. B. Kale and S. Y. Lu, J. Phys.: Condens. Matter, 2007, 19, 1.

59 L. DiLeo, D. Romano, L. Schaeffer, B. Gersten, C. Foster and M. C. Gelabert, J. Cryst. Growth, 2004, 271, 65.

60 X. D. Gao, X. M. Li, S. Zhang, W. D. Yu and J. J. Qiu, J. Mater. Res., 2007, 22, 1815; P. O'Brien, T. Saeed and J. Knowles, J. Mater. Chem., 1996, 6, 1135.

61 J. T. Kloprogge, L. Hickey, R. Trujillano, M. J. Holgado, M. S. S. Román, V. Rives, W. N. Martens and R. L. Frost, Cryst. Growth Des., 2006, 6, 1533; U. Costantino, F. Marmottini, M. Nocchetti and R. Vivani, Eur. J. Inorg. Chem., 1998, 1439; X. Kong, Y. Duan, P. Peng, C. Qiu, L. Wu, L. Liu and W. Zheng, Chem. Lett., 2007, 428-429.

62 W. J. Li, E. W. Shi, Y. Q. Zheng and Z. W. Yin, J. Mater. Sci. Lett., 2001, 20, 1381.

63 M. Castellano and E. Matijevic, Chem. Mater., 1989, 1, 78.

64 L. N. Dem'yanets, D. V. Kostomarov and I. P. Kuz'mina, Inorg. Mater. (Transl. of Neorg. Mater.), 2002, 38, 124; C. D. Chouvy and J. Vedel, J. Electrochem. Soc., 1991, 138, 2538.

65 R. B. Peterson, C. L. Fields and B. A. Gregg, Langmuir, 2004, 20, 5114.

66 B. Wen, Y. Huang and J. J. Boland, J. Phys. Chem. C, 2007, 112, 106; O. Lupan, L. Chow, G. Chai, B. Roldan, A. Naitabdi, A. Schulte and H. Heinrich, Mater. Sci. Eng., B, 2007, 145, 57-66; A. van Dijken, E. A. Meulenkamp, D. Vanmaekelbergh and A. Meijerink, J. Lumin., 2000, 90, 123; A. van Dijken, E. A. Meulenkamp, D. Vanmaekelbergh and A. Meijerink, J. Phys. Chem. B, 2000, 104, 1715 . 